\title{
PENANGANAN KEJANG DEMAM PADA BALITA DI PUSKESMAS LUBUK BAJA KOTA BATAM
}

\author{
Khoirunnisa' Munawaroh, ${ }^{1}$ Isna Aglusi Badri, ${ }^{2}$ Roza Erda ${ }^{3}$ \\ ${ }^{1,2,3}$ STIKes Mitra Bunda Persada Batam \\ Email : khoirunnisamunawaroh@mbp.ac.id
}

\begin{abstract}
ABSTRAK
Kejang demam merupakan penyakit yang terjadi pada usia 6 bulan hingga 5 tahun. Suhu tubuh melebihi $38 \mathrm{C}$ dapat mengakibatkan terjadinya rangsangan kejang. Orang tua balita perlu memahami penanganan pertama pada kejang demam sehingga tidak muncul komplikasi kejang demam. Tujuan dari pengabdian adalah meningkatkan pengetahuan orang tua balita terhadap penanganan kejang. Metode yang digunakan adalah penyuluhan menggunakan media audiovisual dan leaflet. Kegiatan dilaksanakan di Puskesmas Lubuk Baja Kota Batam pada tanggal 3 Januari 2019 dengan jumlah peserta 20 orang. Peserta diberikan pre tes dan pos tes oleh pengabdi menggunakan instrumen yang dibuat oleh pengabdi berdasarkan materi yang diberikan. Hasil kegiatan pengetahuan peserta meningkat dari $40 \%$ menjadi $85 \%$. Penyuluhan bermanfaat untuk meningkatkan pengetahuan orang tua balita. Perawat puskesmas dalam memberikan penyuluhan dapat memanfaatkan media audiovisual.
\end{abstract}

Kata kunci : kejang demam, penyuluhan, leaflet

\section{ABSTRCT}

Febrile seizures are disease that occur in children aged 6 months to 5 years. Body temperature exceeds $38 \mathrm{C}$ can cause seizure stimulation. Parents need to understand the first treatment of febrile seizures so that complications do not appear. The purpose of dedication was to increase the knowledge of parents on seizure management. The method used counseling using audiovisual media and leaflets. The activity was held on January 3, 2019 in Puskesmas Lubuk Baja Batam city with 20 participants. Participants are given a pre-test and test post by using instruments based on the material provided. The results of knowledge activities of participants> 80 increased from $40 \%$ to $85 \%$. Counseling is useful for increasing the knowledge of parents. Nurses at the health center in providing counseling can use audiovisual media.

Key word : Febrile seizures, counseling, leaflet

\section{PENDAHULUAN}

Kejang demam adalah bangkitan kejang yang terjadi karena adanya kenaikan suhu tubuh (suhu rektal diatas $38^{\circ} \mathrm{C}$ ) akibat suatu proses ekstrakranium tanpa adanya infeksi intrakranial atau penyebab lain . Kejang demam sering terjadi pada anak usia 6 bulan sampai 5 tahun karena pada balita kekebalan tubuh masih rendah (Wilson, 2016).

Menurut Penelitian Brian Chung dan Wong Virginia menunjukan bahwa infeksi virus merupakan penyebab terbanyak timbulnya kejang demam. Penelitian ini menunjukan hasil bahwa prevalensi kejang yang disebabkan oleh virus berkisar $40 \%$. Menurut profil kepulauan Riau (2017) salah satu penyakit yang dapat menimbulkan kematian pada balita adalah pneumonia. Peneumonia merupakan penyakit yang dapat disebabkan oleh virus dan bermanifestasi dengan adanya demam.

Demam dengan peningkatan suhu $1{ }^{\circ} \mathrm{C}$ akan dapat mengakibatkan peningkatan metabolisme basal $10-15 \%$ dan peningkatan kebutuhan oksigen 20\% . Kedua hal tersebut membuat perubahan keseimbangan pada membran sel neuron sehingga ion-ion $\mathrm{Na}+$ yang normalnya berada diluar sel menjadi lebih banyak masuk kedalam sel sehingga terjadilah depolarisasi pada sel tersebut yang akan mengakibatkan terjadinya lepasan muatan listrik pada otak sehingga terjadilah bangkitan kejang (Mahmood, 2011) 
Manifestasi kejang demam dibagi menjadi kejang demam simpleks dan kompleks. Kejang demam sederhana (simple febrile seizure) yaitu kejang demam yang berlangsung singkat kurang dari 15 menit dan umumnya akan berhenti sendiri. Kejang berupa umum tonik atau klonik tanpa gerakan fokal. Kejang demam tidak berulang dalam 24 jam, kejang jenis ini merupakan $80 \%$ dari seluruh kejang demam. Kejang demam komplek (complex febrile seizure) yaitu kejang dengan salah satu ciri kejang lama lebih dari 15 menit, kejang fokal atau parsial satu sisi atau kejang umum yang didahului kejang parsial, berulang atau lebih dari satu kali 24 jam.( Arif, 2015)

Penanganan kejang demam di rumah penting untuk diketahui oleh orang tua anak. Respon orang tua apabila terjadi adanya kejang demam sering kali panik dan tentunya. dapat berdampak pada perburukan kondisi pada anak apabila orang tua tidak tahu cara penanganan yang tepat.

Penyuluhan merupakan salah satu upaya untuk meningkatkan pengetahuan pada orang tua balita. Menurut penelitian Udin (2014) penyuluhan dapat meningkatkan pengetahuan dari orang tua dengan nilai $\mathrm{p}<0,05$. Penyuluhan ini dapat dilaksanakan di puskesmas. Puskesmas merupakan pelayanan kesehatan tingkat pertama dimana peran utama adalah memberikan tindakan preventif dan juga rehabilitatif.

Metode pelaksanaan penyuluhan menggunakan audiovisual dan leaflet. Media audiovisual merupakan jenis media yang selain mengandung unsur suara juga mengandung unsur gambar yang dapat dilihat, seperti rekaman video, berbagai ukuran film, slide suara (sanjaya, 2011). Metode ini dianggap lebih meningkatkan resistensi pengetahuan di otak karena minimal melibatkan 2 indra (Jacob, 2009).

Tujuan dari pengabdian ini adalah untuk meningkatkan pengetahuan orang tua terhadap penanganan kejang demam di Puskesmas Lubuk Baja.

\section{METODE}

Metode yang digunakan dalam pengabdian ini adalah penyuluhan menggunakan media audiovisual. Sasaran dari kegiatan ini adalah orang tua balita yang sedang berobat di Puskesmas Lubuk Baja Kota Batam. Kegiatan dilaksanakan pada tanggal 3 Januari 2019 di Puskesmas Lubuk Baja.

Adapun teknis kegiatan dibagi menjadi tahap persiapan, tahap pelaksanaan, dan tahap penilaian. Pada tahap persiapan pengabdi menyiapkan bahan dan materi berdasarkan studi pustaka, melakukan koordinasi dan perijianan ke Puskesmas Lubuk Baja. Pada tahap pelaksanaan sebelum diberikan materi pengabdi memberikan pre test terlebih dahulu. Pengabdi membagikan leaflet untuk memudahkan peserta memahami isi dari materi. Setelah itu penyampaian materi menggunakan media audiovisual, dan sesi tanya jawab. Pada tahap akhir pengabdi melakukan penilaian post test pada peserta. Penilaian pretest dan post test disusun sendiri oleh pengabdi berdasarkan materi yang telah disampaikan.

\section{HASIL DAN PEMBAHASAN HASIL}

Pengabdian masyarakat ini dilaksanakan di puskesmas lubuk baja pada hari kamis tanggal 3 Januari 2018 di ruang tunggu poli puskesmas lubuk baja. Jumlah peserta yaitu 20 peserta. Ada pun hasil sebelum dan setelah kegiatan pengabdian masyarakat adalah sebagai berikut

Tabel 1. Hasil kuesioner sebelum dan setelah penyuluhan

\begin{tabular}{clcc}
\hline no & \multicolumn{1}{c}{ hasil } & sebelum & setelah \\
\hline 1 & baik $(\geq 80)$ & $8(40 \%)$ & $17(85 \%)$ \\
2 & kurang & $12(60 \%)$ & $3(15 \%)$ \\
& $<80$ & & \\
\end{tabular}

\section{PEMBAHASAN}

Hasil pengabdian masyarakat ini diukur dengan peningkatan pengetahuan dari peserta. Dari hasil yang didapatkan setelah penyuluhan pengetahuan peserta dengan nilai $\geq 80$ meningkat menjadi 17 orang (85\%). 
Pendidikan kesehatan melalui media leaflet dan audiovisual membantu peserta pengabdian meningkatkan pengetahuan. Berdasarkan piramida edglar tentang piramida pengalaman belajar menunjukkan bahwa Leaflet dan audiovisual mampu meningkatkan resistensi pengetahuan di dalam otak $>50 \%$ sehingga pemahaman akan suatu pokok bahasan menjadi lebih meningkat (jacob, 2009).

Pada pengabdian ini pengabdi memberikan penjelasan umum terlebih dahulu mengenai kejang demam pada anak. Media audiovisual yang digunakan menekankan pada penanganan pertama ketika anak terjadi kejang dan meyakinkan orangtua untuk tidak panik apabila terjadi kondisi kejang. Tindakan yang dijabarkan meliputi tindakan :

1. Membaringkan anak di tempat rata

2. Mengendorkan pakaian terutama di bagian leher

3. Tidak memberikan obat melalui mulut pada saat kondisi kejang

4. Mengukur suhu tubuh

5. Memiringkan posisi kepala

6. Tidak menahan gerakan anak saat kejang

Secara keseluruhan materi yang disampaikan pengabdi dapat dipahami oleh peserta. Beberapa kendala dalam pelaksanaan kegiatan pengabdian yaitu ada keluarga/pasien yang berlalu lalang di area penyuluhan. Target awal penyuluhan yaitu 30 peserta akan tetapi peserta yang ada hanya 20 peserta.

\section{KESIMPULAN}

Berdasarkan hasil yang didapatkan kesimpulan yang didapatkan pada pengabdian ini yaitu :

1. Pengetahuan peserta yang baik sebelum dilakukan pengabdian yaitu $40 \%$ peserta

2. Pengetahuan peserta yang baik setelah pengabdian meningkat menjadi $50 \%$

3. Penyuluhan menggunakan media audiovisual dan leaflet dapat membantu orang tua meningkatkan pengetahuan mengenai penanganan kejang demam pada balita

\section{Saran}

1. Bagi Orang Tua

Orang tua sebaiknya memperhatikan kondisi demam yang terjadi pada anak. Sebaiknya orang tua melakukan tindakan pencegahan dengan persediaan obat demam dan kompres sebelum terjadinya kejang.

2. Bagi Puskesmas

Penyuluhan dengan metode audiovisual dan leaflet dapat membantu meningkatkan pengetahuan pasien. Metode ini dapat dilaksanakan untuk pendidikan kesehatan dengan tema yang lain.

\section{DAFTAR PUSTAKA}

Arif, R.F. Penatalaksanaan Kejang Demam. Continuing Medical education. CDK-232/ vol. 42 no. 9 , th. 2015

Dinkes Kepri. 2017. Profil Kesehatan Kepri 2017. Dinas kesehatan Kepualauan Riau.

Jacob. 2009. Edgar Dale's Cone Of Experience [Online]. Tersedia Di : Http://Www.Slideshare.Net/Jacobsonsea/ Edgar-Dales-Cone-Of-Experience1

Mahmood KT, Fareed T, Tabbasum R. Management of febrile seizures in children. J Biomed Sci and Res. 2011; 3(1): 353-7.

Udin, MAA. Pengaruh penyuluhan tentang kejang demam anak terhadap pengetahuan orang tua. 2015. Jurnal Media Medika Muda

Sanjaya, W. 2011. Perencanaan dan Desain sistem Pembelajaran. Jakarta : Kencana

Wilson,D., Rodgers, C., Hockenberry, M. 2016. Wong's Essentials of Pediatric Nursing. Elsivier. 